\section{Job Vacancies in Library and Information Appointments}

\author{
Margaret Chapman
}

\section{The Author}

Margaret Chapman is a part-time librarianship lecturer at Bell College of Technology, Hamilton, and Assistant Librarian (job-share) Requests \& Inter-Library Loans, South Lanarkshire Libraries. She is also an Open University student.

E-mail:m.chapman@bell.ac.uk

\section{The Occasion}

This research was prompted by colleagues and students discussing what should be their next move in their career paths.

\section{Abstract \\ Job vacancies from 10 issues of the Library and Information Appointments Supplement, published fortnightly by the Library Association, were input to an Access database. From this queries were run to find where, how many, and what jobs are available, and how many need IT skills and Chartered status.}

\section{Acknowledgement}

The author is grateful to Sandy Sinclair for his IT help, and to Jess Findlay and Sharon McGoldrick, all of Bell College of Technology, School of Business.

\section{Introduction}

The information for this study was taken from ten issues of the Library and Information Appointments Supplement, from 11th February 2000 to 16th June 2000 inclusive. This gave good representation of job vacancies for librarians and information specialists. Not included are vacancies from recruitment agencies, such as TFPL, and voluntary posts, mainly because these would give the study a London bias and thus distort the overall picture.

818 job vacancies were input to an Access database, and these were analysed by geographical area and by sector.

\section{Analysis and Breakdown}

The country was divided as follows:

Scotland

Northern England

Central England **

Southern England

London

Wales

Northern Ireland

Other

** Beds,

Birmingham,

Bucks, Cambs,

Gloucs, Hereford,

Leics, Norfolk, Northants,

Oxon, Rutland, Salop,

Staffs, Suffolk, Warwicks, West Midlands, Worcs.

A field denoting in which counties or major cities the vacancies occurred was also added for further breakdown.

Vacancies were categorised into the following sectors:

$\begin{array}{ll}\text { Academic } & \text { Special } \\ \text { Public } & \text { School } \\ \text { Health } & \text { Other } \\ \text { Legal } & \end{array}$

Further divisions denoted whether positions were full-time or part-time, and whether permanent or temporary. Part-time includes job share, temporary 
means everything that is not permanent, such as " 3 year contract with possibility of renewal", "1 year in the first instance", "6 months maternity leave", as well as temporary appointments which have a definite end. Where no information was given the post was taken to be full-time and permanent for analysis purposes.

Of the 818 jobs, $75 \%$ were permanent positions, and $25 \%$ were temporary. Similarly, most jobs were full-time posts: $83 \%$ full-time, and $17 \%$ some variation of part-time.

Divisions into sectors gave the following results, with staff totals taken from The LIST 2000 Table 4, "The Library Profession by Occupation".

\begin{tabular}{|llll|}
\hline Sector & Nos. & $\begin{array}{l}\text { Staff totals } \\
\text { from LIST }\end{array}$ & $\%$ \\
\hline Academic & 268 & 4,599 & 5.8 \\
Public & 207 & 5,999 & 3.5 \\
Health & 60 & 1,010 & 5.9 \\
Legal & 30 & 3,797 & 5.0 \\
Special & 161 & 1,781 & 3.8 \\
School & 67 & 2,103 & 1.2 \\
Other & 25 & 19,199 & 4.3 \\
\hline Total & 818 & & \\
\hline
\end{tabular}

Defining the level of appointment proved very problematic. Categories of "Manager" and "Assistant" were unhelpful as the term "Manager" could mean anything from a Head of Service . earning c. $£ 50,000 \mathrm{pa}$, to a school librarian described as a "manager with responsibility for running the school resource centre" earning c.£14,000 pa. The additional category of School to distinguish this achieved partial clarification, but trying to categorise appointments in this way proved impossible.

Definitions and descriptions of posts vary widely from sector to sector, from area to area, and again within sectors and within areas, with no standardisation. "Assistant Librarian" could be a senior manager in one vacancy and a low paid junior member of staff in the next. Similarly, "Library Assistant" could be a senior member of staff in one, and a non-qualified person in another.
Increasingly, the term "Librarian" is not used at all, being replaced by "Information Officer", "Information Assistant", "Information Coordinator", "Information Specialist", "Resource Manager", "Learning Facilitator", "Learning Resources Co-ordinator", "Support Officer", "Electronic Resources Assistant", and other similar variations.

Salaries vary widely where published. Private firms rarely publish a salary, and some employers ask for a great deal of expertise for very little remuneration. For example, one employer asked for:

- A degree or postgraduate qualification in librarianship, information science or archive studies

- Good oral and written presentation skills

- Sound experience of enquiry service work

- Sound experience of computerised information retrieval systems

- Ability to work as part of a team

- Computer literacy

- Flexibility, as some Saturday work will be required

- Experience of preparing web pages

- Interest in 20th century history is highly desirable

The starting salary for this post in Central London is $£ 14,130$ pa.

Overall, salaries for qualified librarians were between $£ 11,000$ and $£ 17,000$ pa, with the public sector paying the lowest starting salaries. Two posts described as Manager in the public sector offered a starting salary of $£ 12,912$ pa, full-time. Some adverts gave only the starting salary, some said "salary up to $£ 18,000$ ", which is not helpful as job seekers would like to know what they will actually have to live on now, not several years hence when they have climbed the salary scale.

Standards of job advert also vary widely. For some, a good knowledge of the geography of the UK is essential as there was occasionally no information about the job vacancy's location. No doubt many job seekers know where the Royal Horticultural Society's Lindley Library is, but, as the advert gave no address, no telephone number, no e-mail address, 
(and no closing date), it was difficult to pursue. Perhaps it was a test of candidate's research skills, or an omission by the printer. Other named areas are obviously well known locally, but the AA 2000 road atlas does not list Sandwell in its index.

Giving a county or city would be more helpful. Only one other advert gave no location.

Some posts give little detail of skills, experience, and qualifications required, while others (as above) are specific and demanding. Increasingly, IT skills are asked for, but again the level required varies enormously or is sometimes couched in such vague terms that it is difficult to determine what the employer really wants. For example:- "intuitive IT skills" - what does this mean? "A passion for IT" do they want an applicant who has little knowledge and no qualifications? "Sound working knowledge of computers" - does this mean of how computers work or of the software packages available, or both? "Awareness of ICT" - there cannot be many people left in the entire country who are not aware of ICT. Other phrases, such as "competent in IT", "welldeveloped IT skills", "good IT skills", "excellent IT skills", and "practical IT skills" are only slightly more helpful for prospective applicants. Of the 818 job adverts listed, 493 asked for applicants to have some IT skills.

644 specifically asked for some kind of previous experience. Given the changing nature of job titles and job descriptions, this was not always library experience.

Surprisingly, only 100 of the 818 stated that applicants must be Chartered. Given that the Library Association is embarking on a programme of Charter updating or revalidation for its members, it could be said that this indicates that holding Chartered status is not as necessary for career advancement as the Library Association believes. It appears employers in this study do not see Chartered status as essential, although some offer routes to Chartership. It also indicates that there are many librarians who are not, never will be, and do not need to be Chartered. One employer asked for applicants to have "professional librarian status", but did not specify Chartered status. If the applicants are not Chartered, what criteria does this employer use to determine if applicants have "professional librarian status"?
It can be argued that adverts couched in vague and unspecific terms in all these areas may draw in a much wider range of applicants than those who ask for detailed and specific skills, qualifications and experience.

Geographically, jobs are not evenly spread throughout the UK. To give an idea of the distribution of vacancies England was divided roughly into eight areas.

\begin{tabular}{|lr|}
\hline Scotland & 43 \\
Northern England & 144 \\
Central England & 160 \\
Southern England & 186 \\
London & 258 \\
Wales & 17 \\
Northern Ireland & 2 \\
Other \& unknown & 8 \\
TOTAL: & 818 \\
\hline
\end{tabular}

2 job adverts did not give their locations.

Most vacancies are in London and the South of England. Wales, Northern Ireland and Scotland offer the fewest job opportunities. Despite the difference in population numbers, it appears librarians in these areas have to work much harder to find employment.

\section{Conclusions}

The Library and Information Appointments Supplement is by no means a comprehensive source of job opportunities, although it is the best known among librarians. Many employers will advertise in local and national newspapers or through agencies instead, and these have not been covered here. It is clear, however, that many institutions do have a policy of advertising through the Supplement, as evidenced by the number of times the same employers' names appear in the issues between February and June. Most job opportunities - 33\% are in the Academic sector.

The two most interesting facets of the study, from the author's point of view, were the vagueness of many of the job adverts and the lack of information contained therein, and how few job vacancies - only $5 \%$ - were in Scotland. Given the vast number and variety of libraries in Scotland these results suggest that they find their staff by other means. 
One factor explaining the lack of full information could be the cost of advertising. Employers have to balance the cost of a detailed job and candidate description against their own budgets; but it would be helpful if certain details were compulsory, such as job title (one advert had no job title), and location. The Supplement is delivered to all members of the Library Association throughout the UK and beyond, therefore it would be helpful to know exactly where the vacancies are. Ideally there should also be:

- Employers' name and address

- Brief job description

- Salary

- Qualifications required

- Full-time or part-time, permanent or temporary

- Telephone number and e-mail address

- Closing date

Most adverts did contain this information to a greater or lesser degree, but some were so vague it was difficult to know what they were looking for. Recruitment of staff is a costly and time-consuming business, therefore the better the advert the more likely it is that the employer will find a suitable candidate.

\section{References:}

Library Association Library and Information Appointments, I Ith February- |6th June 2000.

Library and Information Statistics Tables 2000 for the United Kingdom. LISU/Loughborough University. 